\title{
FRAGILITY OF BELARUSSIAN NATIONAL IDENTITY
}

\author{
Vladislav B. Sotirović \\ Mykolas Romeris University, Faculty of Politics and Management, \\ Institute of Political Sciences, Vilnius, Lithuania
}

Belarus is a country also known as Belorussia (White Russia, Weißrussland) in Eastern Europe, which was occupied by the PolishLithuanian common state for centuries until it became a part of Tsarist Russia in the late 18 th century. ${ }^{1}$ Belarus faces many identity problems, but the most important one is the ethnolinguistic challenge to separate Belarussian $^{2}$ national feature. This research paper investigates the focal problems of Belarussian ethnolinguistic, historical, political and national identity features using the methodology of text description and analyzing some relevant academic literature and historical sources. Historical and geopolitical background of Belarussian ethnonational identity question deserves special attention in the paper, which is supported by theoretical framework for ethnic and national identity research by eminent scholars. The fundamental conclusion of the paper is that Belarussian ethnonational identity has been historically developed outside of Belarus as a product of political Russophobia andtherefore it is extremely fragile among the people of Belarus today.

Key Words: Belarus, Belorussia, national identity, Russia, Poland, Slavs, Eastern Europe, Lithuania

\section{National identity}

Common national identity is a focal element for the creation of a national state since a psychological sense of common solidarity cannot be developed without common identity that is based on a fundamental element of group identity. However, such solidarity is a sine qua non of a voluntary decision to live with the others in the same house (i.e., a national state). In other words, the inner stability of each state primarily depends on the level of developed solidarity among citizens. If the level of solidarity is not properly developed then the possibility for self-destruction of a state is an open option. The recent case of

\footnotetext{
1 Jan Palmowski, A Dictionary of Contemporary World History from 1900 to the Present Day, Oxford-New York: Oxford University Press, 2004, 56.

${ }^{2}$ In this article I use the adjective Belarussian, and not Belarusian since the second option is, in fact, the artificial politicized Russophobic construction. In German historiography, for instance, only the first option (Weißrussische) is used [Prof. Dr. Hans-Erich Stier at al. (eds.), Westermann Großer zur Weltgeschichte, Braunschweig: Westermann Schulbuchverlag $\mathrm{GmbH}, 1985,160]$.
} 
ex-Yugoslavia is probably the best example of self-destruction based on the lack of common national solidarity since common national identity of Yugoslavs was never properly developed by state authorities. However, an example of ex-Yugoslavian fragile national identity is not only in contemporary history and the present-day politics. For instance, Europe is currently dealing with the same "Yugoslav syndrome" in Spain concerning the "Catalan Question“. In Eastern Europe, the same problems of national identity are faced by Ukraine and other countries, as well, like Belarus.

It is commonly understood that for the creation and stable existence of an ethnic state (i.e., based on common ethnic group identity) a native language is the most important factor since it is the most natural one among all other factors of common ethnic identity. It is given by birth and it can not disappear or be replaced. It can be suppressed (for instance, by the state authorities) but, nevertheless, it will exist in some form. The language acquisition is the most difficult and the longest process in ethnonational assimilation and it can last for several centuries and generations as, for instance, the story of old Prussian language tells us. Since language is a focal factor of ethnonational identity, every nation with pretension to exist on ethnic (not political) basis tries to prove that it possesses its own language, which has to be internationally recognized as such. If it is such case, a nation, at least according to the political philosophy of German romanticists, has naturaland democratic rights to establish its own ethnonational independent state. Furthermore, the "value" of a nation is measured according to its historically long existence of national statehood as the "historical“ nations are more valuable in comparison to "non-historical“ nations. Those are the reasons why national historiography and philology try to prove that their ethnic groups are historically statehood nations that have separate ethnonational languages. However, in many cases this is not possible due to the lack of historical evidence in sources andtherefore „academicians“ have to activate the instruments of politicized historical interpretation that is usually followed by the creation of fake national historiography. The case of Belarus is, in this matter, only one example among many.

According to some social investigations and surveys in Belarus, only about $20 \%$ of the citizens have a strong belief in the survival of Belarus identity. However, probably the most important fact is that it is possible to keep Belarussian identity in practice while speaking Russian since the so-called Belarussian language is not a live language in the full sense of the meaning any more. ${ }^{3}$ Therefore, the crux of the matter is what the Belarussian language is at all - a separate language, the Russian dialect, the artificial political construction or the native language of Belarussian people? Answering these questions automatically leads to a solution to more important problem: do Belarussian people exist as a separate ethnic nation if they speak Russian?

In many cases religion is one of the most fundamental factors of national identity, even the only fundamental one in some cases (like in the case of BosnianHerzegovinian Muslims). Belarus as a country, like Ukraine, was historically situated between Russia and Poland-Lithuania andtherefore it is viewed as a borderland territory in which Christian Orthodox believers are mainly associated with the Russians while Roman Catholic Christians with the Poles. The fragile Belarussian identity is, in

\footnotetext{
${ }^{3}$ Grigory loffe, "Understanding Belarus: Belarusian Identity", Europe-Asia Studies, Vol. 55, No. 8, 2003, 1241.
} 
essence, originally, shaped within the framework of the Uniates - Greek Catholic believers, who use Orthodox rites, and recognize the dogmatic filioque and the supremacy of the Pope in the Vatican. Henceforth, Belarussian national identity is historically created as the transitional halfway between Russian Orthodoxy and Polish/Lithuanian Roman Catholicism since Belarus is a transitional country on the halfway between Orthodox Russia and Roman Catholic Poland-Lithuania, changing sides according to historical events as the result of the relations between Moscow/ Saint Petersburg and Cracow/Vilnius. Nevertheless, the majority of those who declare themselves as Belarussian today are, in fact, atheists or not strong believers, who do not care much about organized and institutionalized religion. ${ }^{4}$

A geographic,politicaland historical location of a country determines in many cases the identity of its people, which is exactly the case of Belarus. Even the ethnonym of a country is a reflection of its historical development andtherefore for the majority of Belarussian citizens to squeeze their national identity between Russians and Poles continues to be the historical realm of reality. However, during the last century Belarussian nationalism succeeded to rally people around several constructed markers of Belarussian identity: language, history and ethnicity. The case of Belarussian identity is today probably the best example in Eastern Europe of an effective policy for the creation of national identity that is according to Benedict Anderson founded on the "imagined community" feelings. ${ }^{5}$ Nevertheless, the belief in common identity of a certain group, no matter whether such belief has any foundation in reality, has in many cases very important consequences for the creation of a national state or a political association of such imagined ethnonational community.

\section{Ethnonym}

The ethnonym Belarus/Belorussia (White Russia/White Rus') dates back to historical sources (chronicles) at the end of the 14 th century. ${ }^{7}$ Since the origin of the term is not

\footnotetext{
${ }^{4}$ The President of Belarus, Alexander Lukashenko has declared himself an "Orthodox atheist", i.e., the atheist with Christian Orthodox background.

${ }^{5}$ Benedict Anderson, Imagined Communities: Reflections on the Origin and Spread of Nationalism, Revised edition, London: Verso, 2016.

${ }^{6}$ Max Weber, "What is an Ethnic Group", Montserrat Guibernau, John Rex (eds.), The Ethnicity. Reader. Nationalism, Multiculturalism and Migration, Maiden, MA: Polity Press, 1999, 18.

${ }^{7}$ Lithuanian historiography uses for parts of Belarus and Ukraine annexed by the Grand Duchy of Lithuania the term Gudija, which was populated by East Slavs (gudai), who were in such a way separated from Russians (i.e., by Belarussians and Ukrainians today) [Arūnas Latišenka et al., Didysis istorijos atlasas mokyklai nuo pasaulio ir Lietuvos priešistorès iki naujausiuju laiku, Vilnius: Briedis, without a year of publishing, 84]. The Lithuanian historian Zigmas Zinkevičius declaratively claims that the ethnonym Baltarusija (in Lithuanian) (Belorussia in English) is the product of Russian propaganda [Zigmas Zinkevičius, Lietuviai: Praeities, Didybe் ir Sunykimas, Vilnius: Mokslo ir enciklopediju leidybos centras, 2013, 125]. The ethnonym Ruthenians "is the name given to those Orthodox East Slavs who were ruled by non-Orthodox sovereigns. Since its speakers were Orthodox Christians, the Ruthenian language was influenced by Church Slavonic. It was spoken in the territory of contemporary Belarus and Ukraine, and it is the precursor of the modern Belorussian and Ukrainian languages, as well as modern Rusyn” [Barbara Törnquist-Plewa, „Contrasting Ethnic Nationalisms: Eastern Central Europe“, Stephen Barbour, Cathie Carmichael (eds.), Language and Nationalism in Europe, New York:
} 
clarified by the experts its interpretations are (mis)used by many people including Belarussian nationalists for politicaland national purposes. However, the most realistic interpretations of the origins of the ethnonym Belarus/Belorussia are:

1. Belarus (White Rus') originally meant those people of historical Kievan Rus', who did not have obligations to pay tribute to the Tatars of the Golden Horde in the 12th century as opposed to Black Rus', who had such obligations. According to this interpretation, White Rus' were, in essence, free Rus' out of the Tatar hegemony.

2. However, Russian linguist Oleg Trubachev offered a different interpretation. According to the results of his research, there were three groups of the Rus'people: a) Malaya Rus' (Russia Minor) - the original homeland of ethnic Russians where the expansion started; b) Velikaya Rus' (Russia Major) - the territory of colonization from Russia Minor; and c) White Rus' (Alba Russia) - West Russia according to the ancient colortradition of orientation.

There is an unprovable opinion (by Mikolo Ermalovich) that the original term for the present - day Belarus was, in fact, Litva. However, in the course of time the term was usurped by neighboring Slavs and transformed into White Russia. Nevertheless, such hypotheses have not been officially proven in order to become formal academic theories. However, they serve well to certain national-political propaganda orientation. In other words, for the contemporary Belarussian nationalists, the etymology of the term Belarus is not connected with Russia, but rather with the West andtherefore the natural destiny of Belarus is not to be in closer political-economic relations with Russia but with Europe

Oxford University Press, 2000, 193]. The ethnonym Ruthenians is derived from the Latin term Rutheni and it is historically and today very politically applied in order to separate them from the same ethnolinguistic group of East Slavs within Russia called Moscovitae (i.e., those under the administration of Moscow). Ruthenians are, for example, called Rusènai in Lithuanian historiography - East Slavs living in Lithuania, Poland and Hungary [Alfredas Bumblauskas, Senosios Lietuvos istorija 1009-1795, Vilnius: R. Paknio leidykla, 2007, 218]. Hereby, the Western historiography does not leave space for the Russians as an ethnolinguistic group in the Middle Ages since East Slavs were only composed of Ruthenians or Moscovitae. "However, the Ruthenians called themselves ruskije in their own language, the same name Moscovitae gave themselves. Both groups inherited this name from the period when they were united within Kievan Rus' between 800-1240" [Barbara TörnquistPlewa, „Contrasting Ethnic Nationalisms: Eastern Central Europe“, Stephen Barbour, Cathie Carmichael (eds.), Language and Nationalism in Europe, New York: Oxford University Press, 2000, 193]. As a matter of fact, Kievan Rus' was the first ever established state to politically organize East Slavs with Kiev as its capital. Today there are three modern nations, which trace or pretend to trace, their ethnolinguistic origins back to Kievan Rus': Russians, Belarussians and Ukrainians. Nevertheless, the original name of the state is in the modern history best preserved in the form of Russian ethnonym that is telling a lot about which contemporary nation has the most historical, ethnic, linguistic, cultural and moral rights to Kievan Rus' heritage. For instance, the most important law code (codex) of Kievan Rus' is called Russkaya Pravda (1016), and not Ukrainian or Belarus pravda. This codex later became the foundation of the law system in Russia [Jevgenij Anisimov, Rusijos istorija nuo Riuriko iki Putino: Žmonés. IVykiai. Datos, Vilnius: Mokslo ir enciklopediju leidybos centras, 2014, 40]. The ethnonym Ruthenia survived in contemporary history only for the tiny territory in post-WWI Czechoslovakia (in fact in Slovakia). However, in 1945 Subcarpathian Ruthenia was separated from Czechoslovakia and annexed by the Soviet Socialist Republic of Ukraine, where it became renamed into the Transcarpathian Oblast [Chris Hann, „Nation and Nationalism in Central and Eastern Europe“, Gerard Delanty, Krishan Kumar (eds.), The SAGE Handbook of Nations and Nationalism, London-Thousand Oaks-New Delhi: SAGE Publications, 2006,401 ] with a full degree of Ukrainization of the ethnic Ruthenians (i.e., Russians). It is worth to mention that for some Ukrainian historians the epoch of GDL occupation of the biggest part of Ukraine today (1320-1569) is "the darkest time of Ukrainian history" [Andrijus Blanuca et al., Ukraina: Lietuvos epocha, 1320-1569, Vilnius: Mokslo ir enciklopedijų leidybos centras, 2010, 10]. 
(NATO and European Union). Nonetheless, as a matter of historical fact, there was clear absence of a single ethnonym for the territory of Belarus today (and Ukraine) before the Soviet time since, de facto, the Soviet authorities established the modern national identities of both Belarus and Ukraine.

\section{Vilnius}

An idea of Belarussian ethnonational identity, as autonomous from both Russians andPoles, was born in the mid-19th century at Vilnius University in Roman Catholic Lithuania by several professors, who claimed that Belarussian self-awareness can be advocated taking into consideration literary and official state documents of the Grand Duchy of Lithuania (GDL) before the Union of Lublin (signed between Poland and Lithuania in 1569). The essence of their claims was that Slavic inhabitants of GDL inherited cultural-historical legacy and tradition enough to be different from those of neighboring Western Slavic Poles and Eastern Slavic Russians. However, since at that time the present-day territory of Belarus was part of Tsarist Russia, and not of Poland (which did not exist as an independent state at that time), it is not so difficult to conclude that Vilnius-based idea of a separate Belarussian identity, culture, nation and history was primarily designed as an anti-Russian political project. The idea of Belarussian ethnic distinction from Russian national identity was further developed by Vilniusbased literary circle around the journal Nasha Niva (1909-1915).

It can be said that Belarusian nation as "imagined community" was ideologically created and politically framed in Vilnius - the capital of GDL, and subsequently, it is not of any surprise that after the dissolution of the USSR all active leaders of Belarussian (Russophobic) nationalism (like Ukrainian one) enjoy great sympathy and open financial and political support by Lithuanian authorities. Vilnius is today transformed into both the main refugee camp for Russophobic dissidents from Belarus and propaganda center against the legitimate President of Belarus - A. Lukashenko, who is demonized in Lithuania as „the last European dictator" ter of fact, due to historical relations between Lithuania and Belarus, Belarussian opposition leaders consider themselves to be heirs of GDL andtherefore using its coat of arms (called Vytis in Lithuanian) as the nationaland historical insignia of Belarussian nation also tells us very much about their pro-EU/NATO political aspirations. ${ }^{11}$ However, on the

\footnotetext{
${ }^{8}$ On the creation of Belarussian nation see [Nickolas Vakar, Belorussia: The Making of a Nation, Cambridge, USA: Harvard University Press, 1956]. Similarly to the Soviet case, Yugoslav communist authorities created after 1945 three new nations: Montenegrins, Macedonians and Muslims (Bosniaks today).

${ }^{9}$ There is the common Western propaganda pattern that "it is really only the former Soviet republic of Belarus that remains outside the democratic family" [David Gowland et al., The European Mosaic: Contemporary Politics, Economics and Culture, Third Edition, Harlow, England: Prentice Hall, 2006, 421].

${ }^{10}$ M. Donald Hancock et al., Politics in Europe: An Introduction to the Politics of the United Kingdom, France, Germany, Italy, Sweden, Russia, and the European Union, Third Edition, Houndmills: Palgrave Macmillan, 2002, 462.

${ }^{11}$ Belarussian pro-Western political opposition welcomed Minsk-Brussels signature on the EU Partnership and Cooperation Agreement in 1995. However, this agreement "did not come into force because of the deteriorating situation" [David Gowland et al., The European Mosaic: Contemporary Politics, Economics and Culture, Third Edition, Harlow, England: Prentice Hall, 2006, 514]. After the dissolution of the USSR, however, Belarus
} 
other hand, the majority of Belarussian citizens consider themselves as Belarussians in geographic-political terms and/or ethnolinguistic Russians - the fact which basically confirms their pro-Russian political and economic orientation.

\section{History}

Historically, as situated between Poland-Lithuania and Russia, Belarussian Roman Catholics identified themselves as Poles from ethnonational point of view while Belarussian Christian Orthodox believers were self-denominated as Russians andtherefore there was no room for Belarussian identity except for those who did not belong to any of these two groups. The advocates of separate Belorussian ethnonational identity have been essentially promoting their nationalism in opposition to both strong neighbors of Belarus, but today Belarussian nationalism, as well as Ukrainian, is a part of well-orchestrated and sponsored Western policy of "Russophobia Vulgaris“.

In the interwar period (1919-1939) the contemporary territory of Belarus was annexed by Poland and the Soviet Union. At that time Polish authorities recorded only Christian Orthodox believers as of Belarussian ethnonational identity, and not those of Roman Catholic denomination, who were considered as Poles. Such asymmetry in Polish policy of ethnonational identity obviously went in favor of Polonization and de-Russification of North-East Poland. At the same time, the Soviet authorities implemented the policy of Belarussification of Russian Orthodox speakers in East Belarus, which was at that time a part of the USSR in the form of the autonomous Soviet Socialist Republic of Belarus.

\section{Language}

All spoken Slavic languages in Eastern Europe belong to East Slavonic group of languages, which have many similarities. ${ }^{12}$ Regardless of the fact that Russian, Belorussian and Ukrainian languages are traditionally written in the Cyrillic alphabet, there are voices of Belarussian and Ukrainian nationalists to switch to Western Latin graphemes in order to be allegedly more European and less Russian. ${ }^{13}$ The same voices also try to negate a philological

became "Russia's closest partner" and therefore these two countries signed in 1995 a treaty of friendship and cooperation, in 1996 they established a "deeply integrated Community" and in 1997 the Community was converted into the Union which would, according to the project, involve common legislative space and single citizenship [M. Donald Hancock et al., Politics in Europe: An Introduction to the Politics of the United Kingdom, France, Germany, Italy, Sweden, Russia, and the European Union, Third Edition, Houndmills: Palgrave Macmillan, 2002, 452-453].

${ }^{12}$ According to Belgrade University-based Professor Predrag Piper, the Russian language is today spoken by 159 million speakers, Ukrainian by 42.5 million speakers and Belorussian by 9.3 million speakers [Предраг Пипер, Увод у славистику, Књига 1, Београд: Завод за уџбенике и наставна средства, 1998, 25].

${ }^{13}$ The same "alphabetic schizophrenia" has already been applied into practice in Montenegro after its proclamation of independence in 2006. Hereby, the Latin alphabet is, in fact, in use by all state authorities rather than traditional and national Cyrillic, which is the same as Serbian Cyrillic. About the language as a principal national flag in ex-Yugoslavia see [Victor A. Friedman, Linguistic Emblems and Emblematic Languages: On Language as Flag in the Balkans, Columbus, USA: The Ohio State University, 1999]. 
fact that both Belorussian and Ukrainian languages originate in the old Russian language like Russian itself. ${ }^{14}$ A proto-Russian language existed from the 8 th century onwards and became fragmented on the regional basis by the 13th century. A political division of Belarus and Ukraine between Poland-Lithuania and Muscovy-Russia finally broke up the linguistic unity of all East Slavs andtherefore Ukrainian and Belarussian languages became separately standardized in the 19th century more on political than on philological foundations. In Belarussian case, the poetry of Yanka Kupala (1882-1942) and Yakub Kolas (1882-1956) formed the basis for standardized deviation of Belorussian language from Russian, and Vilnius-based journal Nasha niva created before WWI necessary alphabetical, orthographic and grammatical norms for the Belarussian language. This deviation was soon recognized in the Soviet Union as a separate Belorussian language, formally different enough from Russian, and it was further standardized and promulgated. As a consequence of such de-Russification, according to the 1989 Soviet census, there were $77.9 \%$ of Belarussians who officially spoke Belarussian as their first language and only $13.2 \%$ of the local population speaking Russian as the first language. However, these official figures might be misleading in practice as, for instance, according to a survey in $1992,60 \%$ of Belarussian inhabitants preferred to use Russian in everyday life and $75 \%$ favored Belarussian-Russian bilingualism in public life and state institutions. ${ }^{15}$

\section{Statehood}

The possession of a national state is the most important fact of historical pride of any ethnic group and, moreover, in Anglo-Saxon political philosophy, the term "nation" is directly linked to the state or in other words, terms "nation“ and „state" are basically synonyms. Therefore, only those ethnic groups that have their own state, or at least are in the process of striving to create/recreate it, can be called real nations. The others are only ethnic groups living as minorities in not their own political organizations. Subsequently, there are stateless ethnic groups $^{16}$ and statehood nations. Hereby, it is of focal importance to many ethnic groupsto „prove" that they historically belong to the category of statehood nations rather than to stateless minorities. The case of Belarussians is one of the most characteristic examples of this matter and it is in a direct connection with the problem of Belarussian national identity.

At this point it is important to notice that the modern term nation or natio authentically comes from the Latin word nasci that originally meant „to be born“. From the very cultural point

\footnotetext{
${ }^{14}$ Предраг Пипер, Увод у славистику, Књига 1, Београд: Завод за уџбенике и наставна средства, 1998, 144.

${ }^{15}$ Burant S. R., "Foreign Policy and National Identity: A Comparison of Ukraine and Belarus", Europe-Asia Studies, Vol. 47, No. 7, 1995, 1125-1144.

${ }^{16}$ Today the Kurds are probably the largest stateless ethnolinguistic group in the world (up to 30 million). On "stateless nations" see: [Julius W. Friend, Stateless Nations: Western European Regional Nationalisms and the Old Nations, London-New York: Palgrave Macmillan, 2012; Mikael Bodlore-Penlaez, Atlas of Stateless Nations in Europe: Minority Peoples in Search of Recognition, Y Lolfa, 2012; James Minahan, Encyclopedia of the Stateless Nations: Ethnic and National Groups Around the World, I-IV Vols., Second edition, Westport, Connecticut-London: Greenwood, 2016]. On the Kurdish Question see [Merhard R. Izadi, The Kurds: A Concise Handbook, New York: Taylor \& Francis, 1992; Gerard Chaliand, A People Without Country: The Kurds and Kurdistan, Interlink Publishing Group, 1993; Kevin McKiernan, The Kurds: A People in Search of Their Homeland, New York: St. Martin's Press, 2006; Susan Meiselas, Kurdistan in the Shadow of History, Second edition, Chicago: University of Chicago Press, 2008; Michael M. Gunter, The Kurds: A Modern History, Princeton, New Jersey: Markus Wiener Publishers, 2016].
} 
of view, a nation is a group of people who are bonded together by a common language, religion, history, customs and traditions. However, from political point of view, a nation is a group of people who regard themselves as "natural" members of their own political community - the state, and this is historically expressed by the common desire to establish and maintain political sovereignty or at least autonomy (like, for instance, the Catalans in Spain or the Scots in UK). Therefore, if the state is composed of its "natural" members, they are expected to express the highest degree of patriotism or, literally, love of their own fatherland that is, basically, psychological attachment of loyalty based on group solidarity to the national state or the political community by birth. ${ }^{17}$ Subsequently, from the very psychological viewpoint, a nation is a group of people who share loyalty to each other in the form of patriotism. ${ }^{18}$ However, a group of stateless people can lack national pride due to being "inferior" in comparison to historical (statehood) nations regardless of the fact that they share a common cultural and historical identity usually founded on a belief in common descent.

It is very difficult for Belarussian nationalists to find deeper historical foundations of their national statehood, at least before the time of Russian Bolshevik Revolution and Russian Civil War of 1917-1921, when in 1918 the so-called Belarussian People's Republic was formally proclaimed under German military occupation. At the same time, the First Belarussian Congress was convened, but it never took place as it was thwarted by the Bolsheviks, who finally won the civil war and established the Soviet Republic of Belorussia composed of contemporary eastern and central parts of Belarus while its western parts were annexed by reborn Poland according to Bolshevik-Polish Peace Treaty of Riga on March 18th, 1921. ${ }^{19}$ Hereby, the Soviet Belarussia became a founder republic of the USSR in 1922 and therefore it can be treated as the first national state of Belarussians.

We have to keep in mind that the Soviet authorities established a separate socialist republic for each recognized ethnic nation as its national state within the federation system of the Soviet Union. In political theory, "the state is a political association that establishes sovereign jurisdiction within defined territorial borders...a state is characterized by four features: a defined territory, a permanent population, an effective government and sovereignty". ${ }^{20}$ Theoretically, it is quite clear that a state is a synonym for a country meaning that formal international recognition of territorial "independence" is not necessary for it to be treated as a state. Hereby, according to the 1933 Montevideo Convention on the Rights and Duties of States, there are three criteria of statehood:

1. It possesses a stable government.

2. It controls a definite territory.

3. It enjoys the acquiescence of the population. ${ }^{21}$

\footnotetext{
${ }^{17}$ The word "patriotism" is derived from the Latin "patria" (land of a father).

${ }^{18}$ On patriotism see [Igor Primoratz (ed.), Patriotism, New York: Humanity Books, 2002; Charles Jones, Richard Vernon, Patriotism: Key Concepts in Political Theory, Cambridge, UK: Polity Press, 2018].

${ }^{19}$ The Peace of Riga in 1921 is a consequence of the Bolshevik-Polish War of 1919-1921 started by Piłsudski-led Poland in order to annex eastern territories of the pre-1772 Poland not included into the post-WWI Republic of Poland according to the project of the Curzon Line. The treaty was signed after the decisive victory of Józef K. Piłsudski in front of Warsaw in 1920 ("Miracle of the Vistula") [Jan Palmowski, A Dictionary of Contemporary World History from 1900 to the Present Day, Oxford-New York: Oxford University Press, 2004, 557].

${ }^{20}$ Andrew Heywood, Global Politics, Printed in China: Palgrave Macmillan, 2011, 114.

${ }^{21}$ Ibid., 341.
} 
It is obvious that all those three criteria were applicable in the case of Soviet Belorussia andtherefore it can be concluded that the Bolshevik-established Soviet Belarussian Republic within the USSR was historically the first national state of Belarussians. Nevertheless, all crucial forces in fighting for Belarussian statehood were, in fact, of external nature, and not internal, which means that Belarussian statehood is of artificial (in essenceRussophobic) nature.

\section{Mythology}

After the Russian Civil War of 1917-1921 the split of Belarussian identity continues within two camps:

1. The pro-Western nationalists, who gained support from Belarussian activists from Poland for the sake to separate Soviet Belarussia from the USSR.

2. The pro-Russian orientation citizens, who advocated Russophile stance, taking into consideration the focal fact that most citizens of Belarus were of Christian-Orthodox cultural background like Russians and therefore Russian role as a fundamental cultural donor to Belarus had to be respected.

Nevertheless, in the interwar time from 1921 to 1939 , according to the internal passport record of ethnicity, Belarussians existed only on the Soviet, but not on the Polish side.

In search of appropriate historical background of Belarussian national statehood, Belarussian nationalists went to the area of mythology as the only instrument to be used in order to „prove“ their artificial claims. ${ }^{22}$ The case of Belarussian nationalists is a good example how people or some political groups are willing to be engaged in a nationbuilding process, but without previous assurance that their national history is glorious and of statehood nature. Due to the fact that Belarussian history was not adequate at all in regard to Belarussian statehood, it was quite necessary to involve appropriate myths for the sake of, finding" a national state in historical sources. The final purpose was, in fact, to show that Belarussian state independence after the collapse of the USSR is not a new one, and rather the revival of older Belarussian statehood.

In principle, national myths and academic mythology are very useful for the creation of recombination of real history, or it would be better to say, for its rewriting according to political goals and national wishes. ${ }^{23}$ It is clear that academic historians, philologists, linguists, ethnologists or folklorists play a crucial role in the process of creating and spreading myths about national identity regardless of the fact that not much of their work is, in fact, scientifically tested truth.

\footnotetext{
${ }^{22}$ Similarly to Belarussian nationalists, their Croatian colleagues, for instance, did the same in search of longstanding Croatian statehood, which, according to their writings, existed after 1102, when, in fact, Croatia with Slavonia became an integral part of the Kingdom of Hungary on the volunteer basis expressed by Croatian nobility. As a classic example of rewriting Croatian history in this matter, one can offer the following "academic" publications [Ivo Perić, Povijest Hrvata, Zagreb: Centar za transfer tehnologije, 1997; Dragutin Pavličević, Povijest Hrvatske. Drugo, izmijenjeno i znatno prošireno izdanje sa 16 povijesnih karata u boji, Zagreb: Naklada P.I.P. Pavičić, 2000]. Compare with much more academicand scientific approach in [László Kontler, Millennium in Central Europe: A History of Hungary, Budapest: Atlantis Publishing House, 1999].

${ }^{23}$ As a good example how history textbooks are rewritten in an ethnocentric way see [Christina Koulouri (ed.), Clio in the Balkans: The Politics of History Education, Thessaloniki: Center for Democracy and Reconciliation in Southeast Europe, 2002].
} 
As a result of Belarussian statehood mythology, the book by Orlov and Saganovich under the title: Ten Centuries of Belarusian History (862-1918) ${ }^{24}$ was published in 2001 in Vilnius. The book is just one (but remarkable) example of the writings, which direct historiography in a way to be acceptable to the pro-Western orientation of the politics by Belarussian nationalists, who cannot find any Belarussian in the medieval chronicles and other historical sources to understand the Grand Duchy of Lithuania (GDL) not only as the precursor of the modern state of Belarus, but even as the heyday of Belarussian national statehood taking into consideration that at least more than $50 \%$ of GDL inhabitants were East Slavs. ${ }^{25}$ Even after the 1569 Union of Lublin, the Slavs were the majority in GDL.However, according to Belarussian nationalists, they were exactly Belarussians and therefore the East Slavonic language spoken and being in official use by the state authorities in GDL (at least before 1569, when it started to be Polonized) was proclaimed to be the „Old Belarussian“.

The question of language, since a language is considered to be the prime marker of national identity, is of crucial importance for Belarussian nationalists, whose most important task is to „prove" in historical sources that Belarussians used to have and still have a separate language from Russian. In reality, Belarussian language (speech/dialect) was traditionally the rustic or peasant vernacular, which used to be more Russian or Polish as a person became urbanized and searched for a higher social position as the language was refined by urban lifestyleand personal education. ${ }^{26}$ The case of pre-WWII Vilnius is, in this matter, very illustrative: one-third of its inhabitants spoke Yiddish, Polish was spoken in the streets, schools and churches while Belarussian was spoken in the countryside around the city. In 1939 almost no one spoke Lithuanian in Vilnius. ${ }^{27}$

The crucial task for Belarussian camp of the nationalistswas to find the precursor of a modern independent language of Belarus as proof of separate Belorussian nationhood. This search for a major prominent writer, who used Belarussian language led them to Frantsisk Skaryna (a. 1490-a. 1552), whowas well-known for the long period of time as a translator of religious texts into "the simple Russian language“ - the language which became appropriated by Belarussian nationalists as the precursor of modern Belarussian. There are international encyclopedias and other relevant academic publications in which F. Skaryna is clearly labelled as Russian and a translator of the Bible into Russian, and

\footnotetext{
${ }^{24}$ The book was originally published in the Belarussian language and it consists of 200 pages. Similarly to this Belarussian case, the contemporary Croatian historiography claims "thousand years of Croatian statehood".

${ }^{25}$ Lithuanian academic historiography claims that, for instance, „in the mid-16th century Lithuanians constituted about one-third or more of GDL, whose total population may have reached 3 million people...More than half of the population were Slavs, who at various times had lived in the Eastern and South-Eastern lands annexed by GDL" [Zigmantas Kiaupa et al., The History of Lithuania before 1795, Vilnius: Lithuanian Institute of History, $2000,162]$. However, according to Lithuanian history textbooks, in 1430 there were $72 \%$ of East Slavs and in 1569 there were $63 \%$ of them out of total GDL population [Ignas Kapleris, Antanas Maištas, Istorijos egzamino gidas: Nauja programa nuo A iki Ž, Vilnius: Briedis, 2013, 123]. The GDL capital Vilnius (est. 1323) was settled by a community of Russian Orthodox believers even before Lithuania introduced (Roman Catholic) Christianity in 1387 [Stasys Samalavičius, An Outline of Lithuanian History, Vilnius: Diemedis leidykla, 1995, 101].

${ }^{26}$ Grigory loffe, "Understanding Belarus: Belarusian Identity”, Europe-Asia Studies, Vol. 55, No. 8, 2003, 1246.

${ }^{27}$ Timothy Snyder, Tautu rekonstrukcija: Lietuva, Lenkija, Ukraina, Baltarusija 1569-1999, Vilnius: Mintis, 2008, 17.
} 
not into any kind of Belarussian. ${ }^{28}$ The Balarussification of F. Skaryna and his work is an order of the day for Belarussian nationalists as he is, in fact, seen as a father of modern Belarussian national language and therefore, at the same time, of a contemporary Belarussian nation as a separate ethnolinguistic group (especially from Russians).

During the last quarter of a last century, Belarus has also faced with the question of national symbols, which reflect the national identity and political orientation features to a high degree. The politics of national symbols (flag \& coat of arms) are supported by different mythologies and political orientation - pro-Western and pro-Russian. The first group insists on the use of the symbols more related to GDL while the second camp supports the use of the state symbols from the Soviet era officially introduced in 1995 and therefore the current Belarussian flag and national emblem are the only ex-Soviet insignia in the official use. As a result, Belarussians are today the only post-Soviet nation that returned to its Soviet emblems for two reasons:

1. It confirms historical fact that Soviet Belarus was, in fact, the first and therefore authentic national state of Belarussians.

2. It shows the wish of the majority of the population to direct Belarussian political and national orientation towards the East (Eurasian integration) rather than towards the West (NATO/EU integration).

\section{Between West and East}

It has to be explained why today the majority of Belarussian citizens have quite positive attitudes towards Russia - the country viewed as the most reliable partner of Belarus. As a matter of fact, Belarus was after WWII one of the Soviet republics, which mostly benefited from its membership in the USSR for the very reason that it was properly industrialized despite its lack of mineral resources (similarly to the Baltic republics). Belarus peacefully gained its internationally recognized independence as a consequence of the August 26th Coup in Moscow in 1991 followed by the dissolution of the Soviet Union. Since the postSoviet Russia is a legal successor of the USSR, many Belarussians consider it natural to have as good relations as possible with the country from which they quite benefited in the recent past taking also into consideration very close ethnic, linguistic and cultural ties with Russia and Russians. Therefore, among all ex-Soviet republics Belarus is attached to Russia to the greatest degree, which is also seen as a Belarussian protector from Western economic and political policy of brutal liberal-democratic imperialism experienced by all East-Central and South-East European countries after 1991. The Russian language was introduced as equal with Belarussian according to the results of the 1995 plebiscite followed by Belarus joining the Union with Russia in 1999 with the aim to create customs and currency single area, a common parliament and a common judiciary. ${ }^{29}$

On the other hand, it is quite obvious that Belarussian nationalists try to establish popular legitimacy of their own (pro-Western and anti-Russian) version of Belarussian nati-

\footnotetext{
${ }^{28}$ According to Snyder, F. Skoryna was an East Slavic Renaissance actor [Ibid., 24].

${ }^{29}$ Jan Palmowski, A Dictionary of Contemporary World History from 1900 to the Present Day, Oxford-New York: Oxford University Press, 2004, 56.
} 
onal mythology, especially within the domain of historiography for at least three fundamental political reasons and national tasks:

1. To dissociate Belarus from Russia and Russians. ${ }^{30}$

2. To propagate alleged national, historical, political, linguistic, economic and cultural harm inflicted by Russia to Belarus.

3. To create the atmosphere of political Russophobia in Belarus in order to turn the country to the Western direction (NATO/EU). ${ }^{31}$

For the purpose of the pro-Western political orientation of Belarus, GDL has been chosen by many ultranationalists in Belarus as, allegedly, a national state of Belarussians based on three claims:

1. GDL was established and governed not by ethnic Lithuanians, but rather by ethnic Belarus (i.e., Беларусь)

2. The ethnonym Lithuanian(s) is derived from the ethnonym of ancient East Slavs (i.e., Belarus) - Litvinais (Licvinais), who have nothing in common with the Baltic people since they were Belarus Slavs. ${ }^{32}$

3. GDL as a national state of Belarus means that Belarussians are one of the oldest and most powerful European historical nations.

The proponents of anti-Russian and pro-Western course of Belarussian politics use the well-known Western sponsored fake-news propaganda cliché to accuse the legitimate Belarussian President of autocratic governing style, suppression of political opposition, restriction of freedom of speech, closing and controlling non-governmental media and even of sponsoring death squads, which murder the members of political opposition. ${ }^{33}$

\section{Conclusions}

As the most important conclusions of this research paper, the following has to be emphasized:

1. There is still no single Belarussian ethnolinguistic identity to be accepted by the majority of Belarussian citizens today.

\footnotetext{
${ }^{30}$ For the same reason, Lithuanian historiography and political sciences do not consider, in fact, ethnic Russians to exist in the territory of historical GDL calling its East Slavic inhabitants gudai - the term used by GDL authorities and administration for its East Slavs. However, the leading contemporary Lithuanian historian, Edvardas Gudavičius, recognizes that gudai are nothing else but, in fact, the Russians: "Rusus lietuviai vadino gudais" (in English: Lithuanians called Russians Gudai) [Edvardas Gudavičius, Lietuvos istorija I tomas: Nuo seniausių laiku iki 1569 metụ, Vilnius: Akademinio skautų sajūdžio Vydūno fondas Čikagoje-Lietuvos Rašytoju Sajungos leidykla, 1999, 436].

${ }^{31}$ Similarly to Belarus' case of orchestrated Russophobia, in Soviet Lithuania "both the Poles and the Lithuanians unfavorably judged the Russians (or more precisely Russian-speakers) who arrived from the other Soviet republics as undesirable competitors who worsened the social position of the local inhabitants. (The incomers had priority in obtaining work, living space, etc.)" [Vitalija Stravinskiené, "Between Accommodation and Resistance: Interethnic Relations in East and Southeast Lithuania (1944-1953)", Vida Savoniakaitè (ed.), Contemporary Approaches to the Self and the Other, Vilnius: Lithuanian Institute of History, 2014, 180].

${ }^{32}$ Zigmas Zinkevičius, Lietuviai: Praeities, Didybė ir Sunykimas, Vilnius: Mokslo ir enciklopedijų leidybos centras, 2013, 125.

${ }^{33}$ The same cliché was used by the West in the cases of Saddam Hussein, Muammar Gaddafi or Slobodan Milošević.
} 
2. The cultural-political leadership of Belarus is sharply divided into two opposite and antagonistic camps: a) Pro-Westerners; and b) Pro-Russians.

3. Pro-Westerners build up Belarussian ethnogenesis on the foundation of the Grand Duchy of Lithuania as a national state of Belorussians and therefore they struggle for Belarussian inclusion into the Euro-Atlanticist integration framework.

4. Belarussian pro-Westerners blame all focal setbacks of their policy for Moscow crafted Russification of Belarus rather than understanding that the majority of citizens wants as close ties with Russia as possible, but not with NATO and EU.

5. Pro-Russians view Belarussians as the ideological supporters of West-Rusism and therefore they accept political, economic and cultural pro-Moscow orientation.

6. Belarussian nationalistic public workers succeeded to formulate Belarussian separate identity as non-being Polish and Russian. However, they have totally failed to formulate what historically Belarussian exceptional ethnonational identity is.

7. To be Belarussiantoday is much more political-geographic identity expression than ethnolinguistic one.

\section{Bibliography}

[1] Alfredas Bumblauskas, Senosios Lietuvos istorija 1009-1795, Vilnius: R. Paknio leidykla, 2007.

[2] Andrew Heywood, Global Politics, Printed in China: Palgrave Macmillan, 2011.

[3] Andrijus Blanuca et al., Ukraina: Lietuvos epocha, 1320-1569, Vilnius: Mokslo ir enciklopedijụ leidybos centras, 2010.

[4] Arūnas Latišenka et al., Didysis istorijos atlasas mokyklai nuo pasaulio ir Lietuvos priešistorès iki naujausiuju laiku, Vilnius: Briedis, without a year of publishing.

[5] Barbara Törnquist-Plewa, „Contrasting Ethnic Nationalisms: Eastern Central Europe“, Stephen Barbour, Cathie Carmichael (eds.), Language and Nationalism in Europe, New York: Oxford University Press, 2000.

[6] Burant S. R., "Foreign Policy and National Identity: A Comparison of Ukraine and Belarus", Europe-Asia Studies, Vol. 47, No. 7, 1995, 1125-1144.

[7] Charles Jones, Richard Vernon, Patriotism: Key Concepts in Political Theory, Cambridge, UK: Polity Press, 2018.

[8] Chris Hann, „Nation and Nationalism in Central and Eastern Europe“, Gerard Delanty, Krishan Kumar (eds.), The SAGE Handbook of Nations and Nationalism, London-Thousand Oaks-New Delhi: SAGE Publications, 2006.

[9] Christina Koulouri (ed.), Clio in the Balkans: The Politics of History Education, Thessaloniki: Center for Democracy and Reconciliation in Southeast Europe, 2002.

[10] David Gowland et al., The European Mosaic: Contemporary Politics, Economics and Culture, Third Edition, Harlow, England: Prentice Hall, 2006.

[11] Dragutin Pavličević, Povijest Hrvatske. Drugo, izmijenjeno i znatno prošireno izdanje sa 16 povijesnih karata u boji, Zagreb: Naklada P.I.P. Pavičić, 2000.

[12] Edvardas Gudavičius, Lietuvos istorija I tomas: Nuo seniausiu laiku iki 1569 metu, Vilnius: Akademinio skautụ sajūdžio Vydūno fondas Ćikagoje-Lietuvos Rašytojų Sajungos leidykla, 1999

[13] Gerard Chaliand, A People Without Country: The Kurds and Kurdistan, Interlink Publishing Group, 1993.

[14] Grigory loffe, "Understanding Belarus: Belarusian Identity", Europe-Asia Studies, Vol. 55, No. 8, 2003. Benedict Anderson, Imagined Communities: Reflections on the Origin and Spread of Nationalism, Revised edition, London: Verso, 2016. 
[15] Ignas Kapleris, Antanas Maištas, Istorijos egzamino gidas: Nauja programa nuo A iki Ž, Vilnius: Briedis, 2013.

[16] Igor Primoratz (ed.), Patriotism, New York: Humanity Books, 2002.

[17] Ivo Perić, Povijest Hrvata, Zagreb: Centar za transfer tehnologije, 1997.

[18] James Minahan, Encyclopedia of the Stateless Nations: Ethnic and National Groups Around the World, I-IV Vols., Second edition, Westport, Connecticut-London: Greenwood, 2016.

[19] Jan Palmowski, A Dictionary of Contemporary World History from 1900 to the Present Day, Oxford-New York: Oxford University Press, 2004.

[20] Jevgenij Anisimov, Rusijos istorija nuo Riuriko iki Putino: Žmonės. IVykiai. Datos, Vilnius: Mokslo ir enciklopedijų leidybos centras, 2014.

[21] Julius W. Friend, Stateless Nations: Western European Regional Nationalisms and the Old Nations, London-New York: Palgrave Macmillan, 2012.

[22] Kevin McKiernan, The Kurds: A People in Search of Their Homeland, New York: St. Martin's Press, 2006.

[23] László Kontler, Millennium in Central Europe: A History of Hungary, Budapest: Atlantisz Publishing House, 1999.

[24] M. Donald Hancock et al., Politics in Europe: An Introduction to the Politics of the United Kingdom, France, Germany, Italy, Sweden, Russia, and the European Union, Third Edition, Houndmills: Palgrave Macmillan, 2002.

[25] Max Weber, "What is an Ethnic Group", Montserrat Guibernau, John Rex (eds.), The Ethnicity. Reader. Nationalism, Multiculturalism and Migration, Maiden, MA: Polity Press, 1999.

[26] Merhard R. Izadi, The Kurds: A Concise Handbook, New York: Taylor \& Francis, 1992.

[27] Michael M. Gunter, The Kurds: A Modern History, Princeton, New Jersey: Markus Wiener Publishers, 2016.

[28] Mikael Bodlore-Penlaez, Atlas of Stateless Nations in Europe: Minority Peoples in Search of Recognition, Y Lolfa, 2012.

[29] Nickolas Vakar, Belorussia: The Making of a Nation, Cambridge, USA: Harvard University Press, 1956.

[30] Prof. Dr. Hans-Erich Stier at al. (eds.), Westermann Großer zur Weltgeschichte, Braunschweig: Westermann Schulbuchverlag $\mathrm{GmbH}, 1985$.

[31] Stasys Samalavičius, An Outline of Lithuanian History, Vilnius: Diemedis leidykla, 1995.

[32] Susan Meiselas, Kurdistan in the Shadow of History, Second edition, Chicago: University of Chicago Press, 2008.

[33] Timothy Snyder, Tautu rekonstrukcija: Lietuva, Lenkija, Ukraina, Baltarusija 1569-1999, Vilnius: Mintis, 2008.

[34] Victor A. Friedman, Linguistic Emblems and Emblematic Languages: On Language as Flag in the Balkans, Columbus, USA: The Ohio State University, 1999.

[35] Vitalija Stravinskiené, "Between Accommodation and Resistance: Interethnic Relations in East and Southeast Lithuania (1944-1953)", Vida Savoniakaite (ed.), Contemporary Approaches to the Self and the Other, Vilnius: Lithuanian Institute of History, 2014.

[36] Zigmantas Kiaupa et al., The History of Lithuania before 1795, Vilnius: Lithuanian Institute of History, 2000.

[37] Zigmas Zinkevičius, Lietuviai: Praeities, Didybé ir Sunykimas, Vilnius: Mokslo ir enciklopedijų leidybos centras, 2013.

[38] Предраг Пипер, Увод у славистику, Књига 1, Београд: Завод за уџбенике и наставна средства, 1998, 25. 